Document downloaded from:

http://hdl.handle.net/10251/112514

This paper must be cited as:

Pons, J.; Penadés-Plà, V.; Yepes, V.; Martí Albiñana, JV. (2018). Life cycle assessment of earth-retaining walls: An environmental comparison. Journal of Cleaner Production. 192:411-420. doi:10.1016/j.jclepro.2018.04.268

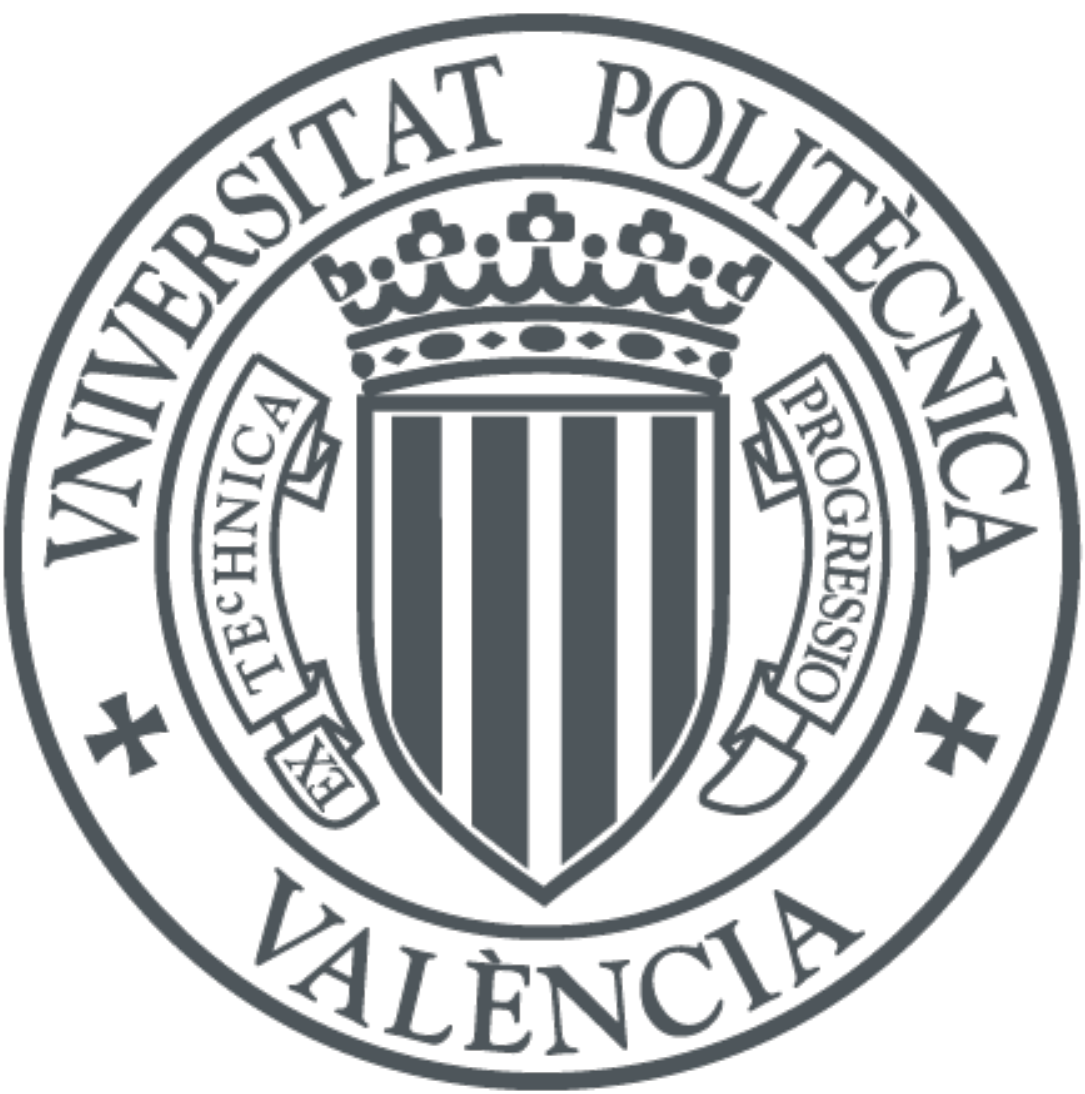

The final publication is available at

http://doi.org/10.1016/j.jclepro.2018.04.268

Copyright Elsevier

Additional Information 


\title{
Life cycle assessment of earth-retaining walls: An environmental comparison
}

\author{
Joaquín J. Pons ${ }^{a}$, Vicent Penadés-Plàa, Víctor Yepes ${ }^{\mathrm{a},{ }^{*} 1}$, José V. Martía \\ ${ }^{a}$ Institute of Concrete Science and Technology (ICITECH), Universitat Politècnica de València, \\ 46022 Valencia, Spain
}

\begin{abstract}
Earth-retaining walls are one of the most common structures in civil engineering, a discipline of the construction sector, which is known to produce one of the highest environmental impacts. Therefore, developing cleaner design and construction practices could contribute to a more sustainable future for our planet. To make a step towards this goal, this study comprises the life cycle assessment (LCA) of the four most common earth-retaining walls built between 1 to $6 \mathrm{~m}$ of height: cantilever walls, gravity walls, masonry walls and gabion walls to obtain the best solutions for the environment. To assess the environmental impacts caused throughout their whole lifecycle including the production, construction, use and end of life phases, we used the OpenLCA software, the ecoinvent 3.3 database and the $\operatorname{ReCiPe}(\mathrm{H})$ method. The associated uncertainties have been considered and the results are provided in both midpoint and endpoint approaches. Our findings show that gabion and masonry walls produce the lowest global impact. On the one hand, gabion walls cause less damage to human health but on the other hand, masonry walls cause less damage to the ecosystems. Furthermore, gravity walls produce similar impacts to gabion and masonry walls between 1 and $3 \mathrm{~m}$ of height as well as fewer impacts than cantilever walls for a height of $4 \mathrm{~m}$. In conclusion, gabion and masonry walls are preferable to concrete walls for heights between 1 and $6 \mathrm{~m}$ and cantilever walls should be used over gravity walls for greater heights than $4.5 \mathrm{~m}$.
\end{abstract}

\section{Keywords}

Life cycle assessment; Sustainability; Earth-retaining wall; ReCiPe.

\footnotetext{
$1 *$ Corresponding author. Phone -34963879563 ; Fax: +34963877569 .

E-mail addresses: joapongu@cam.upv.es (J. J. Pons), vipep12@cam.upv.es (V. Penadés-Plà), vyepesp@cst.upv.es (V. Yepes), jvmartia@cst.upv.es (J. V. Martí).
} 


\section{Introduction}

Over the last years the concerns for the environment have arisen due to the increasing knowledge of how exploiting resources and producing emissions could compromise our future if we continue down this path (National Geographic, 2015). For this reason, the term "sustainable development" was introduced by the Brundtland Commission in 1987 as the "development that meets the needs of the present without compromising the ability of future generations to meet their own needs" (United Nations, 1987). Ever since then, a lot of human effort has been invested to achieve a sustainable development of society by giving more importance to environmental issues and carrying out changes to develop a cleaner production.

The construction industry is one of the most carbon-intensive sectors (Petek Gursel et al., 2014; Ramesh et al., 2010), being responsible to $5 \%$ of the total $\mathrm{CO}_{2}$ emissions as well as one of the industries that requires more materials (Årskog et al., 2004) and one of the main sources of environmental pollution (Shen et al., 2005). In particular, the production of cement and concrete causes the greatest environmental impact of the construction industry (Årskog et al., 2004; Boesch and Hellweg, 2010) due to their high energy demands and their common use in this sector, which will continue to increase over the next years (Taylor et al., 2006). Therefore, developing sustainable construction practices could greatly reduce the environmental impact caused by human activities and make a step towards global sustainability.

To achieve this goal, many authors have developed studies on different aspects of construction to improve the actual methods and reduce the environmental impact. Some authors studied the carbon emissions of concrete projects (Collins, 2010; García-Segura and Yepes, 2016; Martí et al., 2016) along with the emissions caused by the manufacturing of materials (Flower and Sanjayan, 2007; Tait and Cheung, 2016), the embodied energy of construction projects (Wang and Shen, 2013; Wang et al., 2012) and the construction methods used by companies (Serpell et al., 2013; Sierra et al., 2018; Yusof et al., 2016). Other studies focused on the optimization of concrete structures such as columns (de Medeiros and Kripka, 2014), prestressed bridges (GarcíaSegura et al., 2015; Yepes et al., 2015) or earth-retaining walls (Molina-Moreno et al., 2017a, 2017b, Yepes et al., 2012, 2008). Another field of interest is the recycling of concrete (Tam, 2009; Tam et al., 2010) and how it can cut the $\mathrm{CO}_{2}$ emissions through carbonation processes (Dodoo et al., 2009; García-Segura et al., 2014).

However, most of those studies aimed to reduce the carbon emissions, which are the main contributor to global warming, without considering the entire environmental impact caused by the construction processes over the entire life cycle of the structure. To fully quantify and evaluate every impact, life cycle assessment (LCA) is a powerful and versatile tool that can be used for this purpose. Some previous studies used LCA to study the impact caused by the whole life cycle of some structures such as water tanks (Sanjuan-Delmás et al., 2015) or bridges (Penadés-Plà et al., 2017). Other structures of interest are the earth-retaining walls, one of the most common structures in civil engineering used to restrain soil in areas where the landscape needs to be shaped for activities such as roadways, railways or farming. Previous LCA studies of earth-retaining walls have been carried out with success: (Damians et al., 2016) studied the impacts caused by conventional concrete and polymeric walls to select the best sustainable option and (Zastrow et al., 2017) parametrically studied buttressed earth-retaining walls to determine which elements cause the greatest impacts.

Nevertheless, none of those studies focused on environmentally assessing the impacts caused by the life cycle of the most common earth-retaining wall types commonly built at lower heights (1$6 \mathrm{~m}$ ), which are the cantilever, gravity, masonry and gabion walls, shown in Figure 1, to determine which type causes fewer impacts depending on its height. Therefore, the objective of this study is to carry out an LCA analysis according to (ISO, 2006) on the aforementioned wall types. The 
results could be used to obtain the entire environmental impact caused by each wall and to provide a guideline for designers to choose the best type for every height from an environmental point of view. For this task, the ReCiPe method is used to provide both a complete list of every impact and a summary of the damage caused to the three categories: ecosystems, human health and resources to provide designers the ability to choose depending on which factor is more important for the location of their structure. A normalization set is used to provide a global impact score when every factor is considered equally important as well.

\section{Materials and methods}

LCA is a method to investigate and evaluate the potential environmental impacts caused by a product throughout its entire life cycle from raw material extraction to the final disposal or recycling. The LCA of the earth-retaining walls has been carried out according to ISO 14040:2006 (ISO, 2006), following its four main steps: definition of goal and scope, inventory analysis, impact assessment and interpretation of the results. The life cycle impact assessment (LCIA) procedure chosen for this study is ReCiPe 2008 (Goedkoop et al., 2009). The database used for the life cycle inventory is Ecoinvent 3.3 (Ecoinvent Center, 2016).

\subsection{Goal and scope definition}

The main goal of this study's LCA is to analyse and compare the environmental impacts caused by the construction of different earth-retaining wall types to create a guideline for designers to select the most adequate alternative for each height to reduce emissions. The results can be used to quantify the different impacts produced by every wall type, thus obtaining a numerical score for every impact category. An additional global score can be obtained using a normalization set to provide a single result.

\subsubsection{Wall type selection}

Earth-retaining walls are structures used to contain soil or other loose materials when their natural steeps are undesirable, for example, when building linear infrastructures such as railways or roads. The walls keep the soil on two different levels by resisting its lateral pressure and need to be designed to ensure stability against sliding, overturning, excessive foundation pressure and water uplift according to the International Building Code (IBC, 2015).

The wall type depends on its purpose, masonry or rock walls are generally used when lower heights are required as they are composed of rock blocks which are cheaper than concrete alternatives. Gabion walls are particularly chosen for aesthetic purposes over other alternatives in places like river embankments. For greater heights, concrete walls are used as they require less material volume to sustain the soil. Mass concrete gravity walls resist the soil pressure with their own weight and therefore require high amounts of concrete. Reinforced concrete alternatives need to resist flexural moments generated by the terrain, and therefore their thickness increases heavily with the height, making cantilever earth-retaining walls economic up to $10 \mathrm{~m}$ of height and needing the use of buttressed earth-retaining walls, which have greater resistance against flexural moments, for even greater heights.

This study compares the different wall types commonly used between 1 and $6 \mathrm{~m}$ of height: a concrete cantilever wall, a concrete gravity wall, a masonry wall and a gabion wall. This selection of alternatives comprises two different concrete types and two different stone types, providing a wide range of choice for designers even if the project restricts the use of a certain material for the design of the earth-retaining wall. The heights reach up to $6 \mathrm{~m}$ because the use of stone walls is usually limited to that height and mass concrete gravity walls are very rare above $6 \mathrm{~m}$ because the amount of concrete needed for its structural stability hugely increases with height, making them unviable. The reinforced concrete cantilever earth-retaining walls are usually built between 4 and 
$12 \mathrm{~m}$ of height, therefore no designs between 1 and $3 \mathrm{~m}$ have been considered. Buttressed earthretaining walls have not been analysed because they are rarely used at lower heights.

\subsubsection{Phases of the analysis}

The life cycle of the earth-retaining walls has been divided into four phases. The first one is the production of all the materials used to build it, including their transportation to the construction site. The second one is the construction of the earth-retaining wall, including every activity carried out for its building. The third one is the use of the earth-retaining wall during its service life of 50 years according to Spanish code for concrete earth-retaining walls (Fomento, 2008), without maintenance activities. The fourth one is the end of life of the structure, including all the activities needed to demolish the wall, recycle the steel and concrete and to create a sanitary landfill for the soil and rock remnants.

\subsubsection{Functional unit}

To define the functional unit of the earth-retaining walls we need to consider an additional parameter, the height of the wall. This is due to the fact that the amount of materials and wall thickness increase with the height of the wall to resist higher soil pressures. For the cantilever walls, additionally, the ratio of steel reinforcement bars per volume of concrete increases too. The masonry walls studied require no backfill. Since different permissible ground stresses appear to have a small influence on the overall impacts (Zastrow et al., 2017), they are not a relevant parameter and thus have not been considered. Therefore, the functional unit for this study would be a linear meter of wall for a determined height.

\subsection{Inventory analysis}

The inventory analysis involves the collection of relevant inputs of energy and materials required to develop a process, in this case, building a linear meter of an earth-retaining wall and producing the outputs of emissions to the environment derived from its life cycle. This part of the LCA is required to quantify and estimate the expected amounts of resources that will be consumed to create the product and the environmental emissions that will be directly attributable to the life cycle of the product.

\subsubsection{Software}

Ecoinvent (Frischknecht and Rebitzer, 2005) has been chosen as the most suitable database to carry this study because of its worldwide recognition as a scientifically reliable and constantly updated database (Pascual-González et al., 2016). It was developed by Swiss federal offices and researchers of the ETH (Eidgenössische Technische Hochschule Zürich) to harmonize a Life cycle inventory (LCI) for its use in LCA applications (Penadés-Plà et al., 2017). The version used for this study is Ecoinvent 3.3 (Ecoinvent Center, 2016), the most modern one available at the time of this study, for its reliability and precision.

To develop the model, OpenLCA (GreenDelta, GmbH, Berlin, Germany) has been used because of its open source code provides advantages to the scientific community and other public to perform LCA applications (Ciroth, 2007). It also allows the incorporation of location-specific characterization factors for the materials and processes and uncertainty distributions (Hawkins et al., 2013).

\subsubsection{Uncertainty}

There are several uncertainties when developing a model using an already existing database. This is because each process considers different values depending on its geographical location, which is one of the major sources of uncertainty (Hong et al., 2016), as well as the time when the data 
was collected and the technology used. For example, the production of $1 \mathrm{~kg}$ of steel in Switzerland in 2017 would not be the same as the production of $1 \mathrm{~kg}$ of steel in Spain in 2002, the transport distances, the amount of materials and the technology used would differ. For this reason, uncertainty has to be considered in the configuration of the model.

The use of the pedigree matrix (Ciroth et al., 2016) allows the introduction of an uncertainty factor according to five different indicators: reliability, completeness, temporal correlation, geographical correlation and further technological correlation. Using it along with a basic uncertainty factor depending on the type of material or process allows to define the total uncertainty that will be involved when using that data for the configuration of the model.

\subsubsection{Wall design}

The amount of materials per linear meter of wall for every type is provided in Table 1. The dimensions of the cantilever earth-retaining wall considered for this study are the ones provided by (Yepes et al., 2012). For the concrete, a $25 \mathrm{MPa}$ grade is considered with the following dosage: $208 \mathrm{~kg} / \mathrm{m}^{3}$ of cement, $1641 / \mathrm{m}^{3}$ of water, $1110 \mathrm{~kg} / \mathrm{m}^{3}$ of gravel and $919 \mathrm{~kg} / \mathrm{m}^{3}$ of sand. For the reinforcement steel, B500S is considered. The dimensions of the gravity earth-retaining wall have been selected according to the designed procedure developed by (Oliphant, 1997). The same 25 $\mathrm{MPa}$ concrete is used in both concrete earth-retaining walls. Using another concrete with a different strength would result in slightly different results depending on the dosage of the concrete, particularly on the amount of cement and other additives per $\mathrm{m}^{3}$ of concrete. However, for comparison purposes only the $25 \mathrm{MPa}$ grade has been considered because it has the lowest possible strength for earth-retaining walls, resulting in the lowest emissions. The dimensions of the masonry earth-retaining wall have been selected following a guideline developed by the Federal Executive Branch of the Government of Mexico (Llanderal Cázares, n.d.) which provides the amount of materials per linear meter of masonry wall. The dimensions of the gabion earthretaining wall have been selected according to a gabion walls installation guide written by experts from one of the major gabion manufacturers in the USA (Modular gabion systems, n.d.). The masonry wall provided does not require backfill for its construction. The cantilever earth-retaining wall backfill volumes are provided in the article. For the gabion and gravity walls, a backfill volume considering a slope of 1 for the terrain has been considered. The walls have been designed to withstand a service life of 50 years without requiring maintenance activities according to the Spanish code (Fomento, 2008). Additionally, the service limit states of cracking and deflection are checked to guarantee the structural stability of the walls during their service life.

\subsubsection{Life cycle model description}

The life cycle of the earth-retaining walls is divided in 4 phases as depicted in Figure 2. To obtain more accurate results, every activity and material has been selected from the Ecoinvent database unless it was not contained within it, such as the transport distances from the building process or some specific machines which have been modelled as a new process by modelling their emissions and operation times.

The production phase includes every activity needed to produce the construction materials required to build the wall from the excavation of raw materials to their respective transportation to the construction site. For the reinforcement steel of the cantilever wall, recycled steel is used along with new steel, so two different methods of steel production are considered: basic oxygen steelmaking in the blast oxygen furnace for the new steel and an electric arc furnace for the recycled steel. Both processes are different and therefore require different materials, amounts of energy and facilities. Finally, both types of steel are combined in the hot rolling facility, considering $70 \mathrm{~km}$ from their plants to the hot rolling facility, to form the rebar used for the concrete reinforcement, considering $150 \mathrm{~km}$ from the hot rolling facility to the construction site. 
The same distance is considered for the galvanised steel wires for gabion walls. For the concrete, the extraction of gravel, sand and water are considered along with the production of cement and all the processes needed to create concrete, including mixing, clinker production, etc. $25 \mathrm{~km}$ are considered from the concrete plant to the construction site. For the formwork, all the activities needed to create plywood from cutting down trees to cutting the panels of formwork are considered, considering $40 \mathrm{~km}$ from the plywood factory to the construction site. For the stone and soil excavation $10 \mathrm{~km}$ have been considered from the quarry to the construction site. The transport of all the aforementioned materials to the construction site is considered using transport by road.

The construction phase includes every activity needed to build the wall at its location. These activities are different depending on the wall type like the construction materials. For the concrete walls, these activities are: excavating the soil with a hydraulic digger as well as backfilling the wall with the same one; assembling the formwork panels using a cordless screwdriver considering its use for 15 minutes per meter of height; mixing and pouring the concrete using concrete mixer trucks with $6 \mathrm{~m}^{3}$ of capacity; vibrating the concrete using a concrete vibrator for 1 hour per $2 \mathrm{~m}$ of height and compacting the backfill soil using a vibrating tamper for 5 minutes per $\mathrm{m}^{3}$ of soil. For gabion and masonry walls, the use of an excavator machine to fill the gabions or to place the stones on the masonry wall is considered. Additionally, for gabion walls, the welding of the wires to produce the wire mesh and the mounting of the cages is considered.

The use phase includes the carbonation of the concrete during its service life of 50 years for cantilever and gravity walls. Some studies (Collins, 2010; García-Segura et al., 2015, 2014; García-Segura and Yepes, 2016; Possan et al., 2017) declare that concrete can fix $\mathrm{CO}_{2}$ through carbonation, a phenomenon that despite causing structural problems has a positive effect on the environment by absorbing the $\mathrm{CO}_{2}$ from the atmosphere.

A study of the $\mathrm{CO}_{2}$ fixation on concrete during its life cycle was previously done by (Lagerblad, 2005) based on Fick's first law, obtaining the equation [1] where $k$ is the rate factor, $t$ is the service life, $A$ is the area of concrete exposed, $r$ is the amount of $\mathrm{CaO}$ carbonated, $C$ the content of cement per cubic meter of concrete, $K$ is the content of clinker in the cement, $L$ is the content of $\mathrm{CaO}$ in the clinker and $\varepsilon$ is the molecular weight ratio of $\mathrm{CO}_{2} / \mathrm{CaO}$. Equation [1] can be simplified into equation [2] by grouping the constants assuming $r$ is $0.75, L$ is 0.65 and $\varepsilon$ is 0.7857 (Penadés-Plà et al., 2017). Using the data from the concrete, equation [2] can be simplified into equation [3] for our study, considering $k$ is $2.359, t$ is $50, C$ is 279 and $K$ is 90.2 and the exposed area of concrete per linear meter of wall, $A$, depends on the wall height $(H)$ because the width of the wall is $1 \mathrm{~m}$.

$$
\begin{aligned}
& \mathrm{CO}_{2} \text { fixed }(\mathrm{kg})=\frac{k\left(\frac{\mathrm{mm}}{\sqrt{\text { year }}}\right) \cdot \sqrt{t(\text { year })}}{1000} \cdot A\left(\mathrm{~m}^{2}\right) \cdot r \cdot C\left(\frac{\mathrm{kg}}{\mathrm{m}^{3}}\right) \cdot K(\%) \cdot L(\%) \cdot \varepsilon \\
& \mathrm{CO}_{2} \text { fixed }(\mathrm{kg})=0.383 \cdot \frac{k\left(\frac{\mathrm{mm}}{\sqrt{\text { year }}}\right) \cdot \sqrt{t(\text { year })}}{1000} \cdot A\left(\mathrm{~m}^{2}\right) \cdot C\left(\frac{\mathrm{kg}}{\mathrm{m}^{3}}\right) \cdot K(\%) \\
& \mathrm{CO}_{2} \text { fixed }(\mathrm{kg})=1.608\left(\frac{\mathrm{kg}}{\mathrm{m}}\right) \cdot \mathrm{H}(\mathrm{m})
\end{aligned}
$$

Maintenance activities have not been considered during this phase of the analysis because the wall is durable enough to withstand its service life before an unacceptable concrete deterioration is reached (García-Segura et al., 2014), therefore only the $\mathrm{CO}_{2}$ fixation previously described is considered in the analysis. Stone walls are also designed to last 50 years with few maintenance activities. 
The end of life phase includes the excavation of the backfill and stone, the creation of the sanitary landfill, the demolition of the wall using a hydraulic breaker for 20 minutes per $\mathrm{m}^{3}$ of concrete, the transportation of stone and soil to the sanitary landfill $5 \mathrm{~km}$ away and the concrete recycling using a portable crusher with a capacity of $10 \mathrm{~m}^{3}$ per hour, the separation of steel from concrete using magnets and the steel recycling at the facility. The use of the portable crusher for in-situ concrete recycling is due to its numerous advantages over other methods of concrete recycling (Lotfi et al., 2015). The stones of the masonry and gabion walls could be recycled too, but since doing so would not have a significant impact on the life cycle of the earth-retaining wall where they were used, and it is not as common as recycling steel and concrete, we did not consider this solution for our analysis.

The carbonation of the concrete for the remaining time of its use has been considered after it has been crushed. Since the concrete is crushed we can assume that all of it will be carbonated (GarcíaSegura et al., 2014). This means that crushing concrete at the end of life stage is better for the environment due to the carbonation processes that will fix $\mathrm{CO}_{2}$ on the aggregate, reducing the emissions to the atmosphere.

\subsection{Impact assessment}

The objective of the impact assessment is to analyse and quantify the inventory result. This process transforms a large list of emissions and consumed resources caused by the object or activity during its life cycle into environmental indicators which are easier to understand and analyse by scientists or readers. This transformation depends on the impact assessment method chosen for the study and will change the way the results are categorized and presented.

ReCiPe 2008 (Goedkoop et al., 2009) was chosen as the impact assessment method for this study due to its many advantages over other methods. It combines two very common LCIA methods, CML, a midpoint indicator and Eco-indicator 99, an endpoint indicator. On the one hand, the midpoint approach focuses on basic impact categories, such as climate change or ozone depletion, measuring each one with their respective units. On the other hand, the endpoint approach groups several impact categories into three higher damage categories: to human health, to ecosystems and to the availability of resources, measuring each one in Disability Adjusted Life Years (DALY), species per year and U.S. dollars respectively. However, by harmonizing different environmental indicators into bigger categories, the uncertainty for those results increases.

ReCiPe combines both approaches to show the environmental impacts on a very detailed level with the midpoint approach or on an easier to understand level with the endpoint approach. The midpoint approach contains a total of 18 impact categories: Agricultural land occupation (ALO), Climate change (GWP), Fossil depletion (FD), Freshwater ecotoxicity (FEPT), Freshwater eutrophication (FEP), Human toxicity (HTP), Ionizing radiation (IRP), Marine ecotoxicity (MEPT), Marine eutrophication (MEP), Metal depletion (MD), Natural land transformation (NLT), Ozone depletion (OD), Particulate matter formation (PMF), Photochemical oxidant formation (POFP), Terrestrial acidification (TAP), Terrestrial ecotoxicity (TEPT), Urban land occupation (ULO), and Water depletion (WD). These categories provide more precise and reliable results than the endpoint categories, however, they are harder to interpret.

The hierarchist $(\mathrm{H})$ version was chosen to include the long-term perspective of impacts (Khatri et al., 2017), because this study considers the recycling and further use of concrete and steel after the end of life of the structure. The damage categories have been normalized using the Europe $\mathrm{ReCiPe} \mathrm{H} / \mathrm{H}$ [person/year] normalization set to compare their results using points instead of their respective units, providing a global view to the total environmental impact caused. 


\subsection{Interpretation}

The last phase of the LCA is the interpretation of the results. Depending on the objective of the study, the results can be used for different purposes like studying which stages of the construction cause greater impacts, which materials or processes are the main contributors or comparing different techniques for the same alternative. In our study, our main objective is to select which alternative among the four options causes less environmental impacts for every height. For this reason, considering both the endpoint and midpoint is greatly beneficial for the interpretation of the results. The midpoint approach can be used to study a particular impact category while the endpoint approach can be used to study one of the three damage categories or combine them to obtain a global impact score.

\section{Life cycle assessment results}

The uncertainty has been considered for every result of the LCA, using Monte Carlo simulations (1000 simulations) to obtain the probabilistic uncertainty analysis. Nevertheless, only the mean values are displayed on graphs to provide a better comparison between the different wall types.

\subsection{Midpoint approach}

As stated before, the midpoint impact categories provide more reliable information, even though, they are harder to interpret due to the high number of categories and their actual effect on the environment. This creates a complete environmental profile which can be used for specific purposes or problems with the downside of not providing a global impact. Using all the information provided with this approach, a solution can be chosen when some impact categories are considered particularly important for the project, for instance, the global warming potential or the fossil depletion. An example of the full results obtained including the associated uncertainty between the database and the study are provided in Table 2 for a height of $4 \mathrm{~m}$ including the coefficients of variation. The coefficients of variation are higher for concrete walls due to the associated uncertainties of the concrete production processes and the machinery used for building them, which is particularly noticeable on the global warming potential (GWP). On the other hand, stone walls have lower uncertainties because the processes required to produce their materials and to build the walls are different, which results in a different uncertainty too. For this reason, there is only a significant difference between the uncertainty of the concrete walls and the stone walls. However, the comparison is done between the mean values of the impacts for all cases because they are the representative ones. Figures 3, 4 and 5 show every midpoint impact for heights of 2, 4 and $6 \mathrm{~m}$ respectively. These midpoint impacts are displayed relatively to the biggest impact for every category.

To complement those graphs and identify the main source of every impact to understand its value, Table 3 shows the material or activity that mostly contributes to every midpoint impact category and its contribution in percentage between 1 and $6 \mathrm{~m}$ for every wall excluding the cantilever walls shorter than 4 . The first number shows the contribution for the shortest wall while the second number shows the contribution for the tallest wall. This information can be used to interpret whether the contribution percentage increases or decreases with the height depending on which number is bigger. As a remark, the impact caused by every wall type on the natural land transformation category is negative, which means that the construction of the walls has a positive effect on the environment for that category. This is due to the revegetation processes carried out after the landfill for stone and soil has been created at the end of life stage. For this reason, the main contributor is actually the creation of the landfill with a negative contribution over $100 \%$, because its positive effect surpasses the negative effects of the other activities. The symbol (-) is displayed before the percentages to represent their negative contribution to the natural land transformation. 
In Figure 3 there are no results for the cantilever wall because there are no cantilever walls considered for a height of $2 \mathrm{~m}$. The biggest difference between wall types for an impact category can be observed on the agricultural land occupation (ALO), where the gravity wall causes almost 10 times more impact than stone walls for a height of $2 \mathrm{~m}$. This is due to the production of plywood for formwork which requires to cut down trees. In Figures 4 and 5 every wall type is considered. For heights of 4 and $6 \mathrm{~m}$, cantilever and gravity walls also show a huge difference when compared to masonry and gabion walls that do not require wood for their construction. Another remarkable difference can be found for the terrestrial ecotoxicity (TEPT) between gabion walls and the other types due to the high contribution of the galvanised steel wire production for the gabion cages. Gabion walls also show a much higher metal depletion (MD) impact than masonry and gravity walls due to the use of galvanised steel wires. Nevertheless, cantilever walls cause as much as three times the metal depletion of gabion walls for a height of $6 \mathrm{~m}$ because they require high quantities of steel for the reinforcement. Regarding the natural land transformation (NLT), gravity walls cause more impact than other alternatives because the only material buried in landfill is the backfill soil and they require less backfill than cantilever walls. Therefore, the landfills created for gravity walls are smaller and the revegetation too, which causes more impact than the revegetation processes for other wall types that require more soil or stone. For a height of $4 \mathrm{~m}$, gravity walls caused the major impact in four categories while cantilever walls caused the major impact in 12 categories. However, for a height of $6 \mathrm{~m}$, gravity walls caused the major impact in eight categories and cantilever walls in eight categories too. The use of reinforcement steel is the major contributor to most impact categories in cantilever walls. This means that cantilever walls are worse for the environment than gravity walls for a height of $4 \mathrm{~m}$.

Climate change is emphasized among the other midpoint impact categories due to the importance of $\mathrm{CO}_{2}$ emissions for global warming. Figure 6 represents the total emission per linear meter of wall depending on the height and type. The masonry wall has the lowest impact for a height of 1 meter while gabion walls have the lowest impact between 2 and $6 \mathrm{~m}$ of height. Gravity walls have similar but slightly lower impacts than masonry walls for 2 and $3 \mathrm{~m}$ of height, however, they become the worst option for heights between 4 and $6 \mathrm{~m}$ due to the increase in the amount of concrete to sustain the soil. Cantilever walls are slightly cleaner than masonry walls for heights of 4 and $5 \mathrm{~m}$. For concrete walls, concrete production is the major contributor to climate change, ranging from $43.1 \%$ to $54.2 \%$ in cantilever walls and $82.9 \%$ to $112,4 \%$ in gravity walls. However, if we consider the crushing and recycling of concrete, carbonation reduces those amounts by $9.6 \%$ to $-12.4 \%$ in cantilever walls and $-17.5 \%$ to $-33.8 \%$ in gravity walls between 1 and $6 \mathrm{~m}$ of height. Note that the total $\mathrm{CO}_{2}$ emissions throughout the life cycle of the structure are the $100 \%$, even if the concrete production causes greater emissions than this value, the fixation of $\mathrm{CO}_{2}$ decreases the value and adding the other sources of emissions results in the total amount of $\mathrm{CO}_{2}$. Therefore, crushing concrete at the end of life phase of concrete structures greatly reduces $\mathrm{CO}_{2}$ emissions through carbonation processes.

\subsection{Endpoint approach}

To obtain global results and easier to compare impact categories the endpoint approach is required. The three categories can be determinants for choosing a wall type over the others depending on which impact could cause more damage to the environment on the construction site, the human health if it's built close to a city or town, the ecosystem if it's close to a protected area or resources if they are scarce on the area. This provides designers with the cleaner alternative for every category depending on which one has more weight on the area of study. Using a normalization set, the endpoint categories can be harmonised to a single unit rather than their own ones, obtaining a global impact result. It can be useful when there is no preference to reduce a particular category of damage, so they are all considered of equal importance, obtaining a total score for every impact produced by the construction of the earth-retaining wall. 
The damage caused to the ecosystem measured in lost species per year is shown in Figure 7. Masonry walls cause the lowest damage with similar results to the gabion walls and gravity walls only at 1 and $2 \mathrm{~m}$ of height. Cantilever walls cause more damage than gabion and masonry walls but less than gravity walls for every height. Concrete and plywood produce the biggest contributions in concrete walls, cement in masonry walls and the galvanised steel wires in gabion walls. Gravity walls increase their impact almost exponentially due to the high volumes of concrete required.

The damage caused to human health measured in disability-adjusted life years is shown in Figure 8. Gravity, masonry and gabion walls cause almost the same damage for a height of 1 meter, but masonry walls cause the lowest damage of the three alternatives. For a height of $2 \mathrm{~m}$, masonry walls increase their damage while gabion and gravity walls remain producing a similar amount of damage, but gravity walls cause less damage than gabion walls. However, gabion walls become the best alternative from $3 \mathrm{~m}$ of height to 6 , and gravity walls cause more damage than masonry walls for heights of 4 to $6 \mathrm{~m}$. Cantilever walls cause more damage than gravity walls for a height of $4 \mathrm{~m}$ but less for greater heights. Cement, concrete and steel are the main contributors among other activities and materials like stone and the wall demolition.

The damage caused to resources measured in U.S. dollars is shown in Figure 9. Gravity, masonry and gabion walls cause similar damages between 1 to $3 \mathrm{~m}$ of height. Gravity walls become worse for this damage category for greater heights than $3 \mathrm{~m}$ and cantilever walls are the worst alternative in terms of resources for every height studied, however, it can be predicted by looking at the trends that gravity walls would become worse for greater heights. Gabion walls are better than masonry walls for heights of 2 and $3 \mathrm{~m}$ but masonry walls are better for the remaining heights.

These three damage categories could have different weights and importance depending on the location of the construction site or the designer's point of view. For this reason, they have been divided on separate graphs to allow the reader of this study to apply his judgement depending on how important every damage category is considered to be. Additionally, using the normalization set Europe ReCiPe $\mathrm{H} / \mathrm{H}$, a global impact score is represented in Figure 10 considering that every endpoint damage category is equally important. Masonry walls are the best alternative for 1-meter high walls and gabion walls between 2 and $6 \mathrm{~m}$ of height. However, masonry walls cause almost the same environmental impact as gabion walls for every height studied. Gravity walls remain competitive with gabion and masonry walls between 1 and $3 \mathrm{~m}$ of height, becoming worse for taller walls. Cantilever walls become better than gravity walls around $4.5 \mathrm{~m}$ of height.

Furthermore, the relative importance of each phase of the life cycle on the total impact of $4 \mathrm{~m}$ high walls is represented in Figure 11. The production phase contributes the most to the impact of every wall type due to the extraction of materials and the required processes and transport. It has the major contribution in gravity walls because they require high volumes of concrete. The construction phase has a major contribution in concrete walls as a result of the machinery required to build the formwork, and to pour and vibrate the concrete, whereas stone walls only require machinery for the placement of the stones during the construction phase. During the use phase since maintenance activities are excluded from the analysis, only carbonation is considered for the concrete walls, resulting in a slightly negative impact through the fixation of $\mathrm{CO}_{2}$. The end of life phase has a very small contribution in concrete walls, even a negative one for gravity walls, due to the same reason, the carbonation of concrete causes a negative impact. On the other hand, it has a bigger contribution in stone walls, which also results in a smaller contribution of the other phases, because there is no fixation of $\mathrm{CO}_{2}$ on the stones. 


\section{Conclusion}

The construction sector has one of the greatest influences on climate change. For this reason, carrying out an environmental assessment of this sector could reduce its emissions and lower its environmental impact. A complete LCA using the Ecoinvent database and uncertainties is applied to earth-retaining walls to obtain their impact on different ecological factors using some of the most relevant midpoint categories and the three endpoint categories as well as the global impact score.

This LCA study compares the environmental impacts caused by four different earth-retaining wall types of different heights between 1 and $6 \mathrm{~m}$. The results show that concrete walls usually produce more impacts than their stone counterparts. However, gravity walls stay competitive with masonry and gabion walls between 1 and $3 \mathrm{~m}$ of height for every damage category excluding ecosystems due to the high increment in the volume of concrete required for their construction. Gravity walls are also cleaner than cantilever walls for $4 \mathrm{~m}$ of height, which is the usual height for the use of reinforced concrete over mass concrete for earth-retaining walls, thus from an environmental point of view the minimum height for the use of reinforced concrete should be 4.5 $\mathrm{m}$ instead. This is a key factor for designers to consider when the project requires a concrete earth retaining-wall. Between the stone walls, for 1-meter high walls, masonry walls produce the lowest impact on every category. For the rest of heights, gabion walls are slightly cleaner than masonry walls with almost the same score for every category excluding the damage caused to human health. This category is lower for gabion walls while the damage caused to the ecosystem is lower for masonry walls. This factor could determine which alternative is chosen depending on which category is deemed to be the most important one for the project.

To reduce the $\mathrm{CO}_{2}$ emissions, crushing concrete for recycling at the end of life stage of concrete earth-retaining walls reduced the climate change category by $-9.6 \%$ to $-12.4 \%$ in cantilever walls and $-17.5 \%$ to $-33.8 \%$ in gravity walls. This is due to the carbonation processes in the crushed concrete which can be used as gravel for other new construction projects such as road aggregates or backfill soil. Therefore, crushing concrete to allow its whole carbonation through time and recycling it for other uses notably reduces the environmental impact. This is an important decision for the end of life phase of the structure and has advantages over just demolishing the wall and burying concrete in a landfill.

The growing concern for the environment has made the environmental impact one of the major determining factors for selecting a design over others in civil engineering. Therefore, environmental guidelines could be essential to consider which solution is the best one for a construction project rather than using only economic criteria. Using LCA could help to reduce the environmental impacts caused by the complete life-cycle of many typical structures. This is due to the fact that knowing which types or dimensions offer cleaner solutions is essential to develop sustainable construction practices. If these practices are implemented, the environmental impact of the construction sector could be reduced and therefore, contribute to global sustainability. This paper creates a guideline for the environmental impacts of earth-retaining walls, one of the most common structures in civil engineering. The midpoint and endpoint impact categories are considered to provide both approaches. Every graph and result presented in this paper could be used by engineers to select the cleanest structure depending on its height, location and the most relevant damage or impact category.

\section{Acknowledgments}

This research was funded by the Spanish Ministry of Economy and Competitiveness along with FEDER funding (Project BIA2017-85098-R). 


\section{References}

Årskog, V., Fossdal, S., Gjørv, O.E., 2004. LIFE-CYCLE ASSESSMENT OF REPAIR AND MAINTENANCE SYSTEMS FOR CONCRETE STRUCTURES, in: Proceedings of the International Workshop on Sustainable Development and Concrete Technology. Beijing.

Boesch, M.E., Hellweg, S., 2010. Identifying Improvement Potentials in Cement Production with Life Cycle Assessment. Environ. Sci. Technol. 44, 9143-9149. doi:10.1021/es100771k

Ciroth, A., 2007. ICT for environment in life cycle applications openLCA - A new open source software for life cycle assessment. Int. J. Life Cycle Assess. 12, 209-210. doi:10.1065/lca2007.06.337

Ciroth, A., Muller, S., Weidema, B., Lesage, P., 2016. Empirically based uncertainty factors for the pedigree matrix in ecoinvent. Int. J. Life Cycle Assess. 21, 1338-1348. doi:10.1007/s11367-013-0670-5

Collins, F., 2010. Inclusion of carbonation during the life cycle of built and recycled concrete: influence on their carbon footprint. Int. J. Life Cycle Assess. 15, 549-556. doi:10.1007/s11367-010-0191-4

Damians, I.P., Bathurst, R.J., Adroguer, E.G., Josa, A., Lloret, A., 2016. Sustainability assessment of earth-retaining wall structures. Environ. Geotech. jenge.16.00004. doi:10.1680/jenge.16.00004

de Medeiros, G.F., Kripka, M., 2014. Optimization of reinforced concrete columns according to different environmental impact assessment parameters. Eng. Struct. 59, 185-194. doi:10.1016/J.ENGSTRUCT.2013.10.045

Dodoo, A., Gustavsson, L., Sathre, R., 2009. Carbon implications of end-of-life management of building materials. Resour. Conserv. Recycl. 53, 276-286. doi:10.1016/J.RESCONREC.2008.12.007

Ecoinvent Center, 2016. Ecoinvent v3.3 [WWW Document]. URL http://www.ecoinvent.org/database/older-versions/ecoinvent-33/ecoinvent-33.html (accessed 9.12.17).

Flower, D.J.M., Sanjayan, J.G., 2007. Green house gas emissions due to concrete manufacture. Int. J. Life Cycle Assess. 12, 282-288. doi:10.1065/lca2007.05.327

Fomento, 2008. EHE-08.

Frischknecht, R., Rebitzer, G., 2005. The ecoinvent database system: a comprehensive webbased LCA database. J. Clean. Prod. 13, 1337-1343. doi:10.1016/J.JCLEPRO.2005.05.002

García-Segura, T., Yepes, V., 2016. Multiobjective optimization of post-tensioned concrete box-girder road bridges considering cost, CO2 emissions, and safety. Eng. Struct. 125, 325-336. doi:10.1016/J.ENGSTRUCT.2016.07.012

García-Segura, T., Yepes, V., Alcalá, J., 2014. Life cycle greenhouse gas emissions of blended cement concrete including carbonation and durability. Int. J. Life Cycle Assess. 19, 3-12. doi:10.1007/s11367-013-0614-0

García-Segura, T., Yepes, V., Alcalá, J., Pérez-López, E., 2015. Hybrid harmony search for sustainable design of post-tensioned concrete box-girder pedestrian bridges. Eng. Struct. 92, 112-122. doi:10.1016/J.ENGSTRUCT.2015.03.015

Goedkoop, M., Heijungs, R., Huijbregts, M., De Schryver, A., Struijs, J., Van Zelm, R., 2009. ReCiPe 2008 First edition Report I: Characterisation. 
Hawkins, T.R., Singh, B., Majeau-Bettez, G., Strømman, A.H., 2013. Comparative Environmental Life Cycle Assessment of Conventional and Electric Vehicles. J. Ind. Ecol. 17, 53-64. doi:10.1111/j.1530-9290.2012.00532.x

Hong, J., Shen, G.Q., Peng, Y., Feng, Y., Mao, C., 2016. Uncertainty analysis for measuring greenhouse gas emissions in the building construction phase: a case study in China. J. Clean. Prod. 129, 183-195. doi:10.1016/J.JCLEPRO.2016.04.085

IBC, 2015. 2015 International Building Code [WWW Document]. URL https://codes.iccsafe.org/public/document/toc/542/ (accessed 9.22.17).

ISO, 2006. International Organization for Standardization. Environmental Management-Life Cycle Assessment—Principles and FrameworkVolume 2006, Page 14040 [WWW Document]. URL https://www.scopus.com/record/display.uri?eid=2-s2.085020746982\&origin $=$ inward\&txGid=d64bcdf5d544b40cd79f1b83433371b5 (accessed 9.22.17).

Khatri, P., Jain, S., Pandey, S., 2017. A cradle-to-gate assessment of environmental impacts for production of mustard oil using life cycle assessment approach. J. Clean. Prod. 166, 988997. doi:10.1016/J.JCLEPRO.2017.08.109

Lagerblad, B., 2005. Carbon dioxide uptake during concrete life cycle - State of the art.

Llanderal Cázares, R., n.d. Muros de Contención [WWW Document]. URL http://www.sagarpa.gob.mx/desarrolloRural/Documents/fichasCOUSSA/Muros de contención.pdf (accessed 9.12.17).

Lotfi, S., Eggimann, M., Wagner, E., Mróz, R., Deja, J., 2015. Performance of recycled aggregate concrete based on a new concrete recycling technology. Constr. Build. Mater. 95, 243-256. doi:10.1016/J.CONBUILDMAT.2015.07.021

Martí, J. V., García-Segura, T., Yepes, V., 2016. Structural design of precast-prestressed concrete U-beam road bridges based on embodied energy. J. Clean. Prod. 120, 231-240. doi:10.1016/J.JCLEPRO.2016.02.024

Modular gabion systems, n.d. Gabion walls design [WWW Document]. URL http://www.gabions.net/downloads/Documents/MGS_Design_Guide.pdf (accessed 9.22.17).

Molina-Moreno, F., García-Segura, T., Martí, J. V., Yepes, V., 2017a. Optimization of buttressed earth-retaining walls using hybrid harmony search algorithms. Eng. Struct. 134, 205-216. doi:10.1016/J.ENGSTRUCT.2016.12.042

Molina-Moreno, F., Martí, J. V., Yepes, V., 2017b. Carbon embodied optimization for buttressed earth-retaining walls: Implications for low-carbon conceptual designs. J. Clean. Prod. 164, 872-884. doi:10.1016/J.JCLEPRO.2017.06.246

National Geographic, 2015. Global Warming and Climate Change Effects: Information and Facts [WWW Document]. Natl. Geogr. Mag. URL

http://www.nationalgeographic.com/environment/global-warming/global-warming-effects/ (accessed 9.18.17).

Oliphant, J., 1997. The outline design of earth retaining walls.

Pascual-González, J., Guillén-Gosálbez, G., Mateo-Sanz, J.M., Jiménez-Esteller, L., 2016. Statistical analysis of the ecoinvent database to uncover relationships between life cycle impact assessment metrics. J. Clean. Prod. 112, 359-368. doi:10.1016/J.JCLEPRO.2015.05.129

Penadés-Plà, V., Martí, J. V., García-Segura, T., Yepes, V., 2017. Life-Cycle Assessment: A 
Comparison between Two Optimal Post-Tensioned Concrete Box-Girder Road Bridges. Sustainability 9, 1864. doi:10.3390/su9101864

Petek Gursel, A., Masanet, E., Horvath, A., Stadel, A., 2014. Life-cycle inventory analysis of concrete production: A critical review. Cem. Concr. Compos. 51, 38-48. doi:10.1016/J.CEMCONCOMP.2014.03.005

Possan, E., William, A.T., Aleandri, G.A., Emerson, F.F., dos Santos, A.C.P., 2017. CO2 uptake potential due to concrete carbonation: A case study. Case Stud. Constr. Mater. 6, 147-161. doi:10.1016/J.CSCM.2017.01.007

Ramesh, T., Prakash, R., Shukla, K.K., 2010. Life cycle energy analysis of buildings: An overview. Energy Build. 42, 1592-1600. doi:10.1016/J.ENBUILD.2010.05.007

Sanjuan-Delmás, D., Hernando-Canovas, E., Pujadas, P., de la Fuente, A., Gabarrell, X., Rieradevall, J., Josa, A., 2015. Environmental and geometric optimisation of cylindrical drinking water storage tanks. Int. J. Life Cycle Assess. 20, 1612-1624. doi:10.1007/s11367-015-0963-y

Serpell, A., Kort, J., Vera, S., 2013. Awareness, actions, drivers and barriers of sustainable construction in Chile. Technol. Econ. Dev. Econ. 19, 272-288. doi:10.3846/20294913.2013.798597

Shen, L.-Y., Lu, W.-S., Yao, H., Wu, D.-H., 2005. A computer-based scoring method for measuring the environmental performance of construction activities. Autom. Constr. 14, 297-309. doi:10.1016/J.AUTCON.2004.08.017

Sierra, L.A., Yepes, V., García-Segura, T., Pellicer, E., 2018. Bayesian network method for decision-making about the social sustainability of infrastructure projects. J. Clean. Prod. 176, 521-534. doi:10.1016/j.jclepro.2017.12.140

Tait, M.W., Cheung, W.M., 2016. A comparative cradle-to-gate life cycle assessment of three concrete mix designs. Int. J. Life Cycle Assess. 21, 847-860. doi:10.1007/s11367-016$1045-5$

Tam, V.W.Y., 2009. Comparing the implementation of concrete recycling in the Australian and Japanese construction industries. J. Clean. Prod. 17, 688-702. doi:10.1016/J.JCLEPRO.2008.11.015

Tam, V.W.Y., Tam, L., Le, K.N., 2010. Cross-cultural comparison of concrete recycling decision-making and implementation in construction industry. Waste Manag. 30, 291-297. doi:10.1016/J.WASMAN.2009.09.044

Taylor, M., Tam, C., Gielen, D., 2006. Energy Efficiency and CO 2 Emissions from the Global Cement Industry Energy Efficiency and CO 2 Emission Reduction Potentials and Policies in the Cement 4-5.

United Nations, 1987. Our Common Future: Report of the World Commission on Environment and Development.

Wang, E., Shen, Z., 2013. A hybrid Data Quality Indicator and statistical method for improving uncertainty analysis in LCA of complex system - application to the whole-building embodied energy analysis. J. Clean. Prod. 43, 166-173.

doi:10.1016/J.JCLEPRO.2012.12.010

Wang, T., Lee, I.-S., Kendall, A., Harvey, J., Lee, E.-B., Kim, C., 2012. Life cycle energy consumption and GHG emission from pavement rehabilitation with different rolling resistance. J. Clean. Prod. 33, 86-96. doi:10.1016/J.JCLEPRO.2012.05.001

Yepes, V., Alcalá, J., Perea, C., González-Vidosa, F., 2008. A parametric study of optimum 
earth-retaining walls by simulated annealing. Eng. Struct. 30, 821-830.

doi:10.1016/J.ENGSTRUCT.2007.05.023

Yepes, V., González-Vidosa, F., Alcalá, J., Villalba, P., 2012. $\mathrm{CO}_{2}$-Optimization Design of Reinforced Concrete Retaining Walls Based on a VNS-Threshold Acceptance Strategy. J. Comput. Civ. Eng. 26, 378-386. doi:10.1061/(ASCE)CP.1943-5487.0000140.

Yepes, V., Martí, J. V., García-Segura, T., 2015. Cost and $\mathrm{CO}_{2}$ emission optimization of precast-prestressed concrete U-beam road bridges by a hybrid glowworm swarm algorithm. Autom. Constr. 49, 123-134. doi:10.1016/J.AUTCON.2014.10.013

Yusof, N., Abidin, N.Z., Zailani, S.H.M., Govindan, K., Iranmanesh, M., 2016. Linking the environmental practice of construction firms and the environmental behaviour of practitioners in construction projects. J. Clean. Prod. 121, 64-71. doi:10.1016/J.JCLEPRO.2016.01.090

Zastrow, P., Molina-Moreno, F., García-Segura, T., Martí, J. V., Yepes, V., 2017. Life cycle assessment of cost-optimized buttress earth-retaining walls: A parametric study. J. Clean. Prod. 140, 1037-1048. doi:10.1016/J.JCLEPRO.2016.10.085 


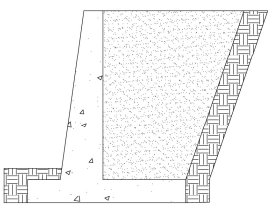

Cantilever Wall

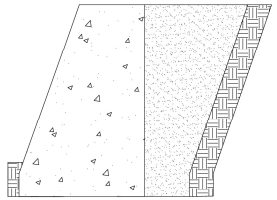

Gravity Wall

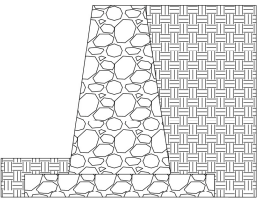

Masonry Wall

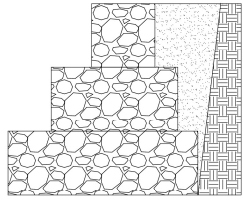

Backfill

4 Concrete

Q1 Stone

酳 Soil

Fig. 1. Earth-retaining wall types

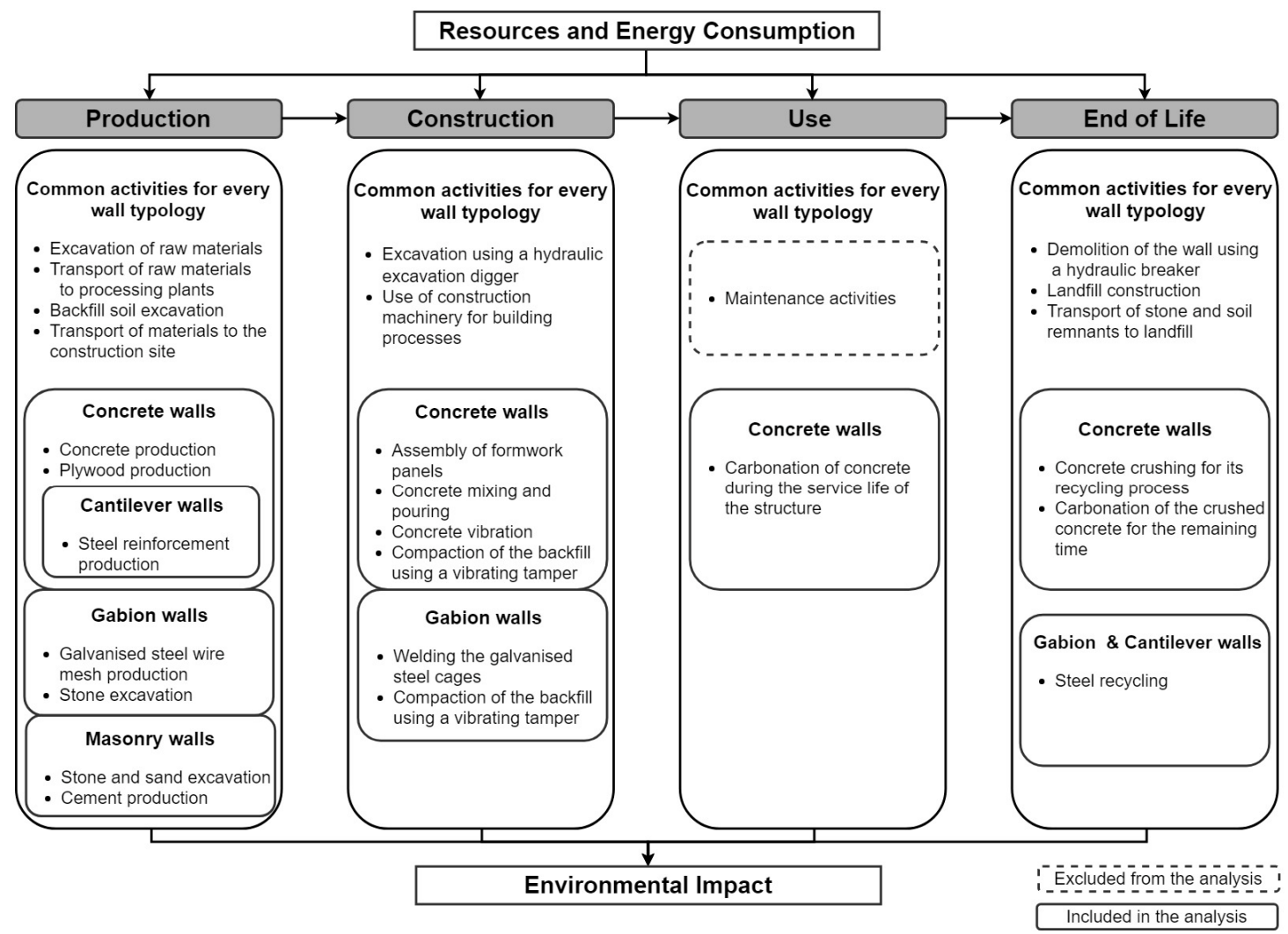

Fig. 2. Life cycle of the earth-retaining walls 


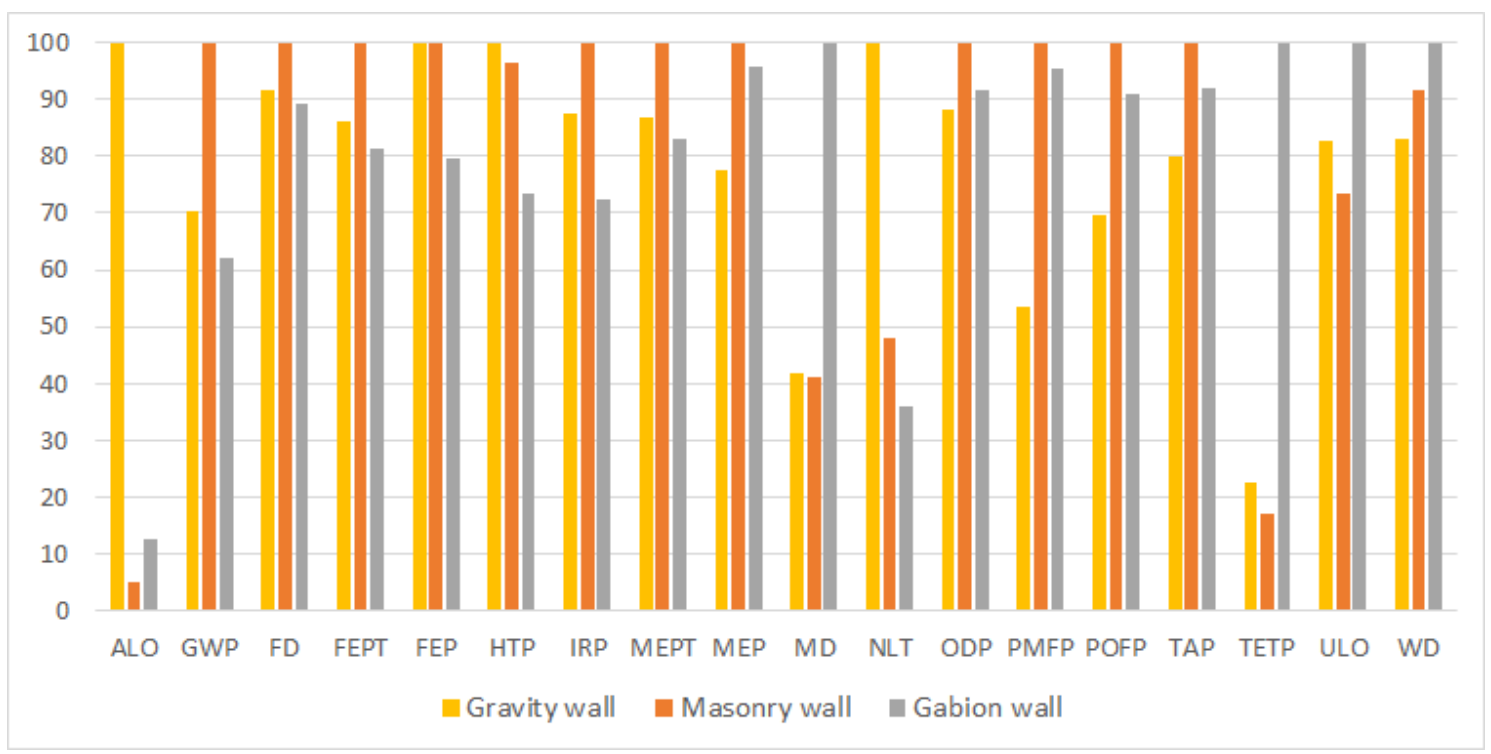

Fig. 3. Midpoint impacts for $2 \mathrm{~m}$ high walls

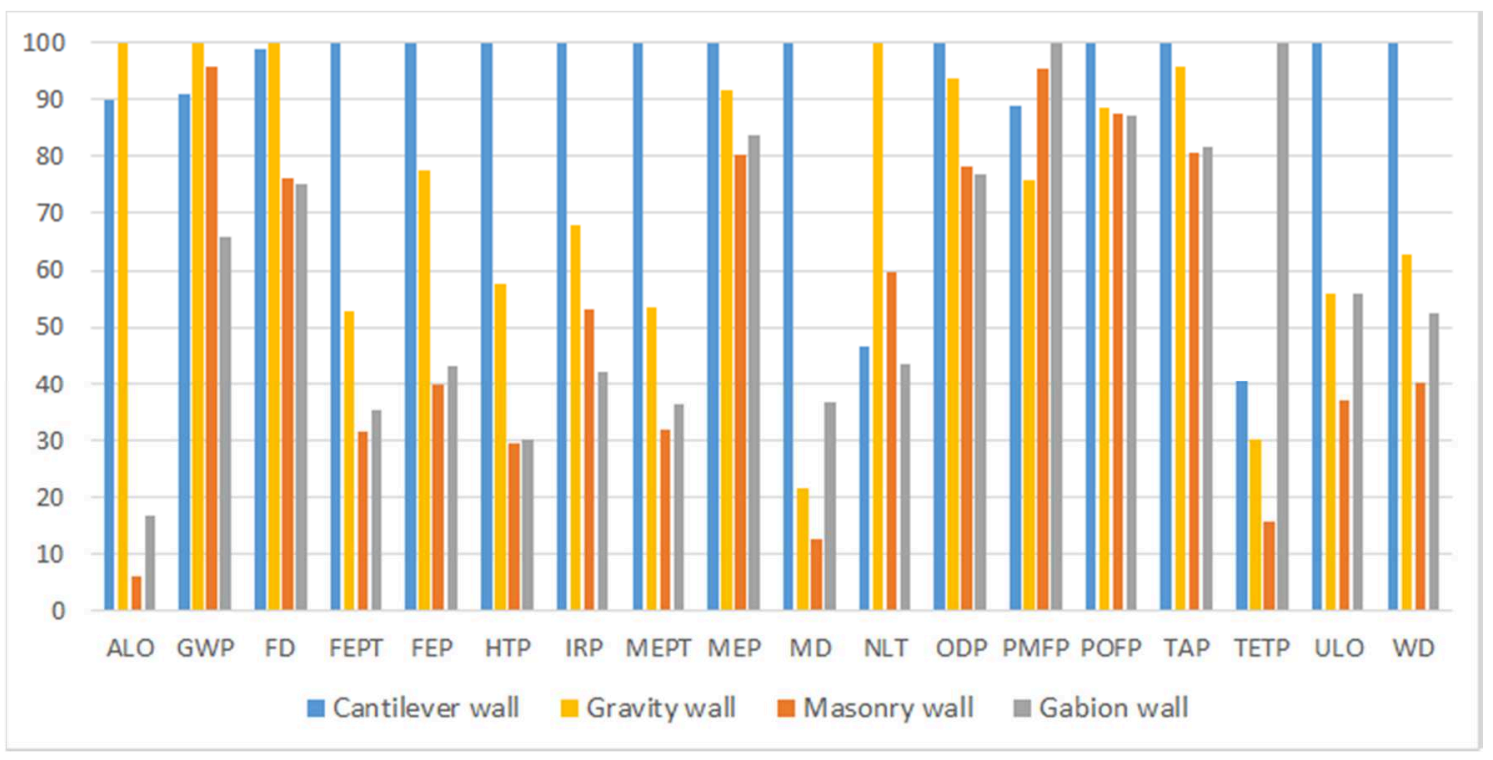

Fig. 4. Midpoint impacts for $4 \mathrm{~m}$ high walls 


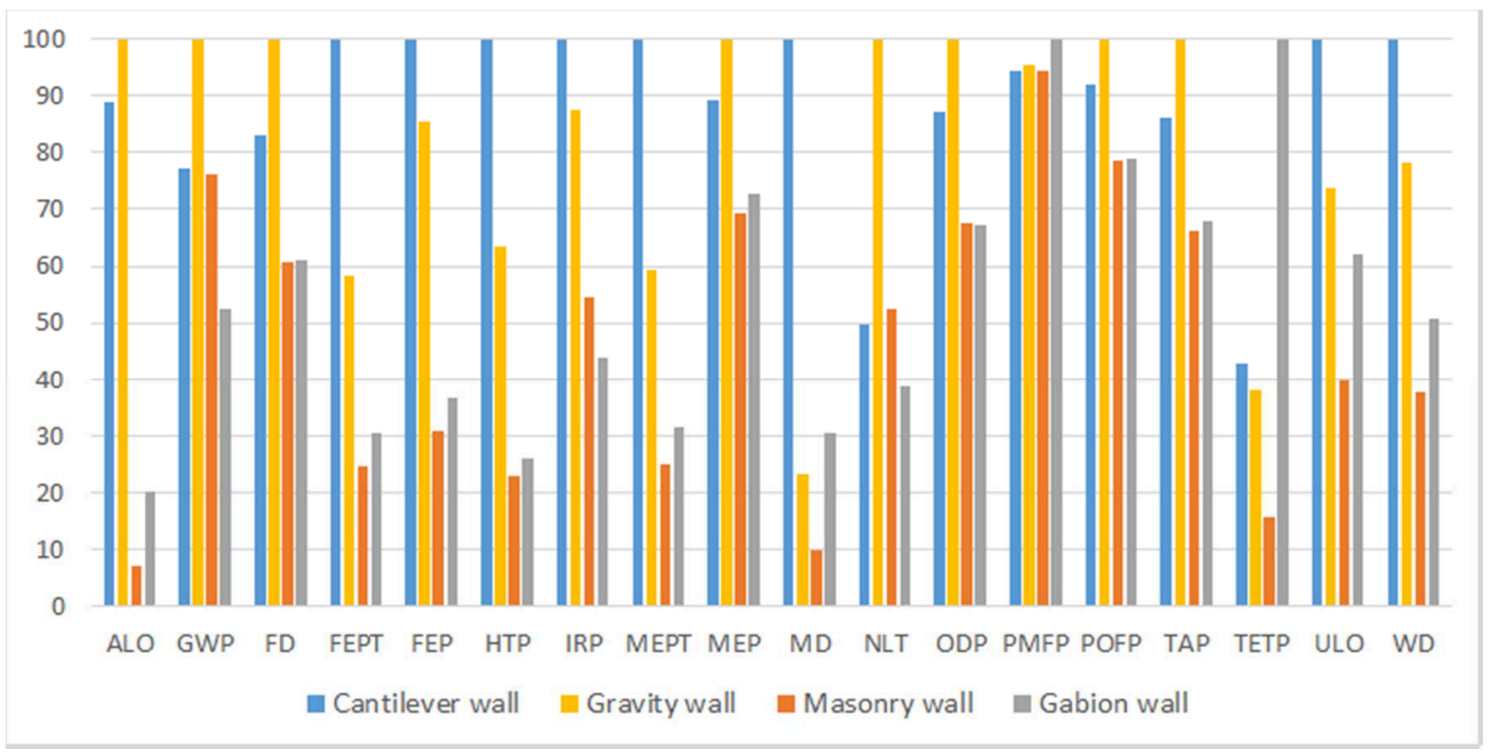

Fig. 5. Midpoint impacts for $6 \mathrm{~m}$ high walls

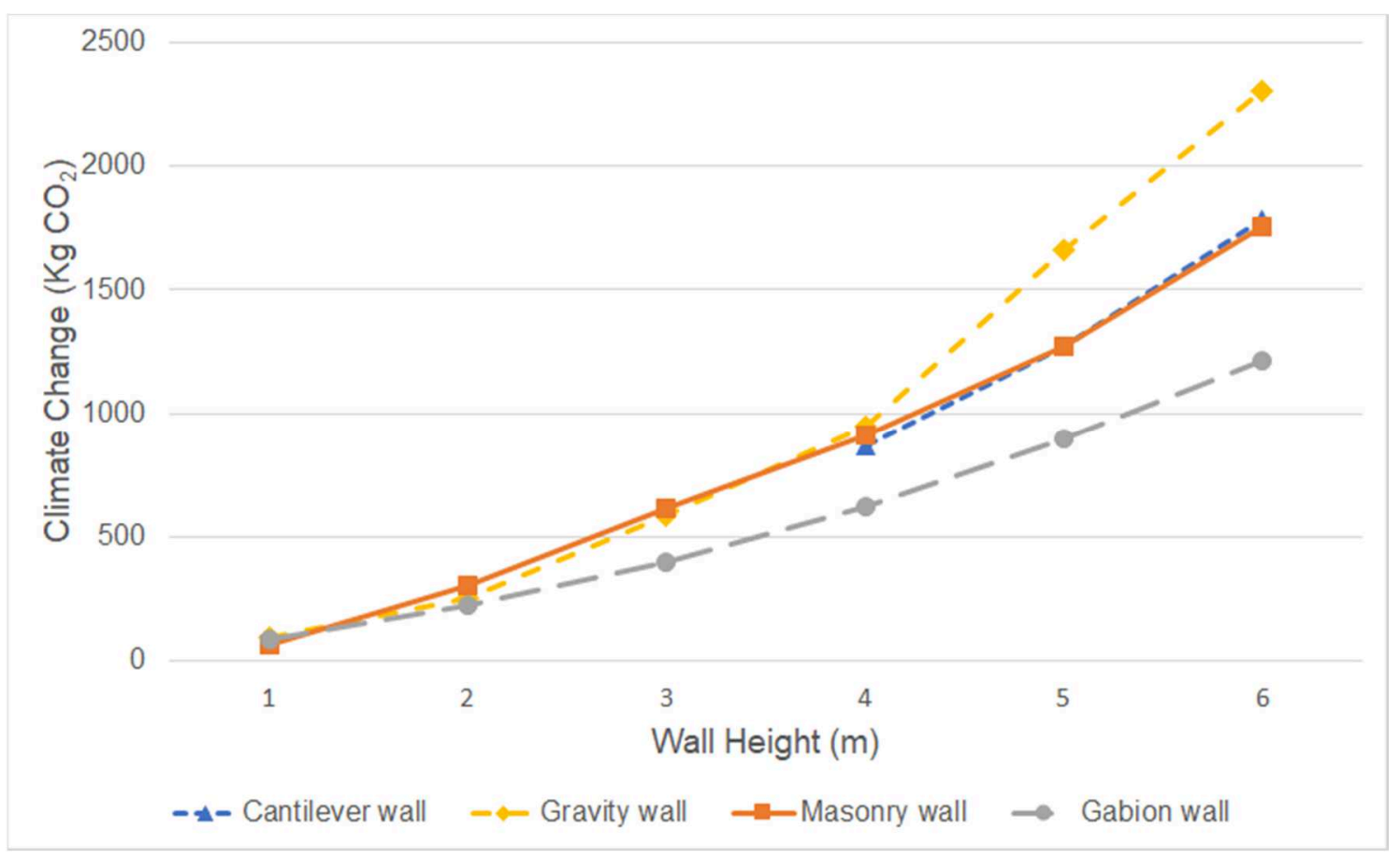

Fig. 6. Development of Climate Change with regard to wall height 


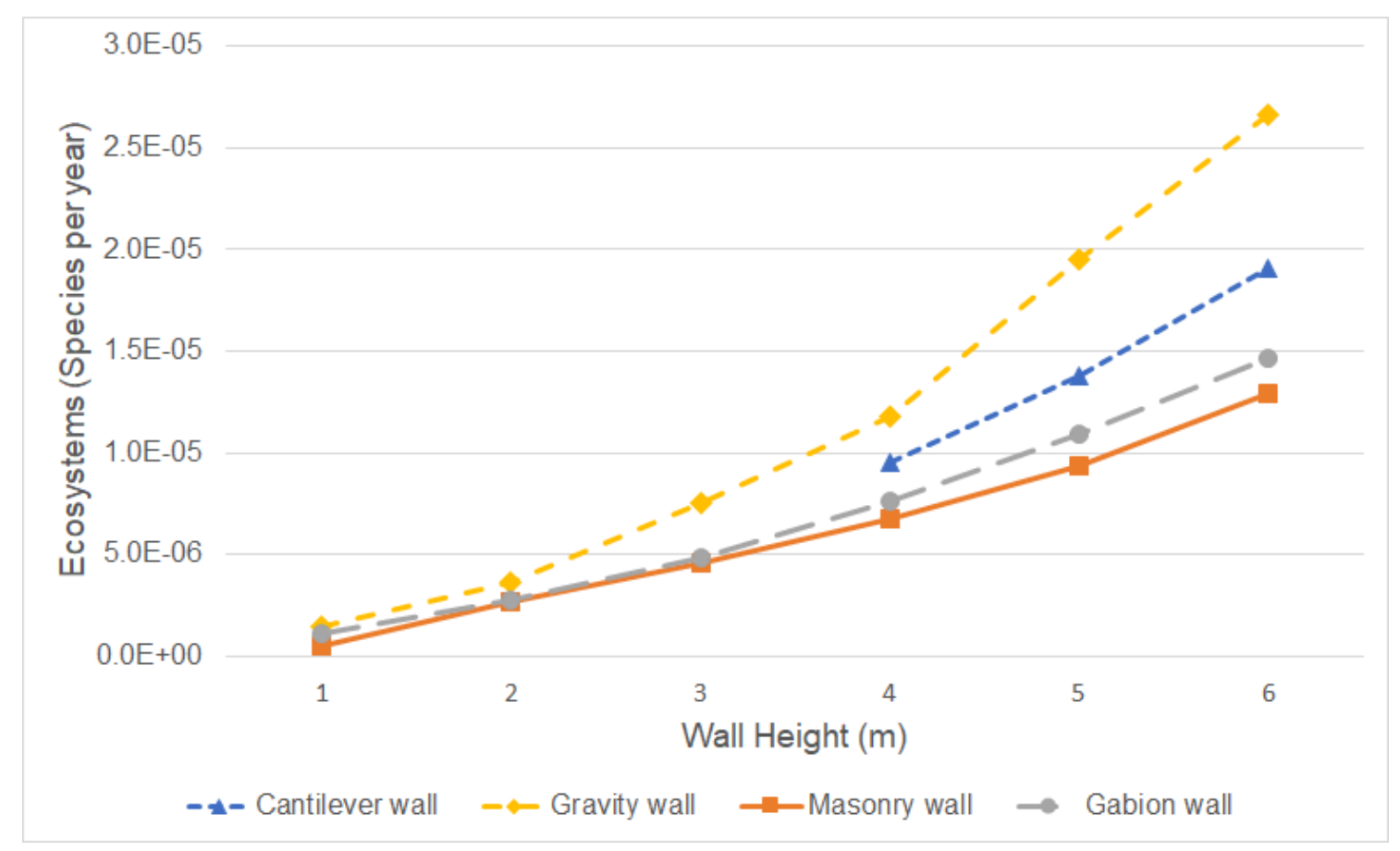

Fig. 7. Development of the ecosystems endpoint impact with regard to wall height

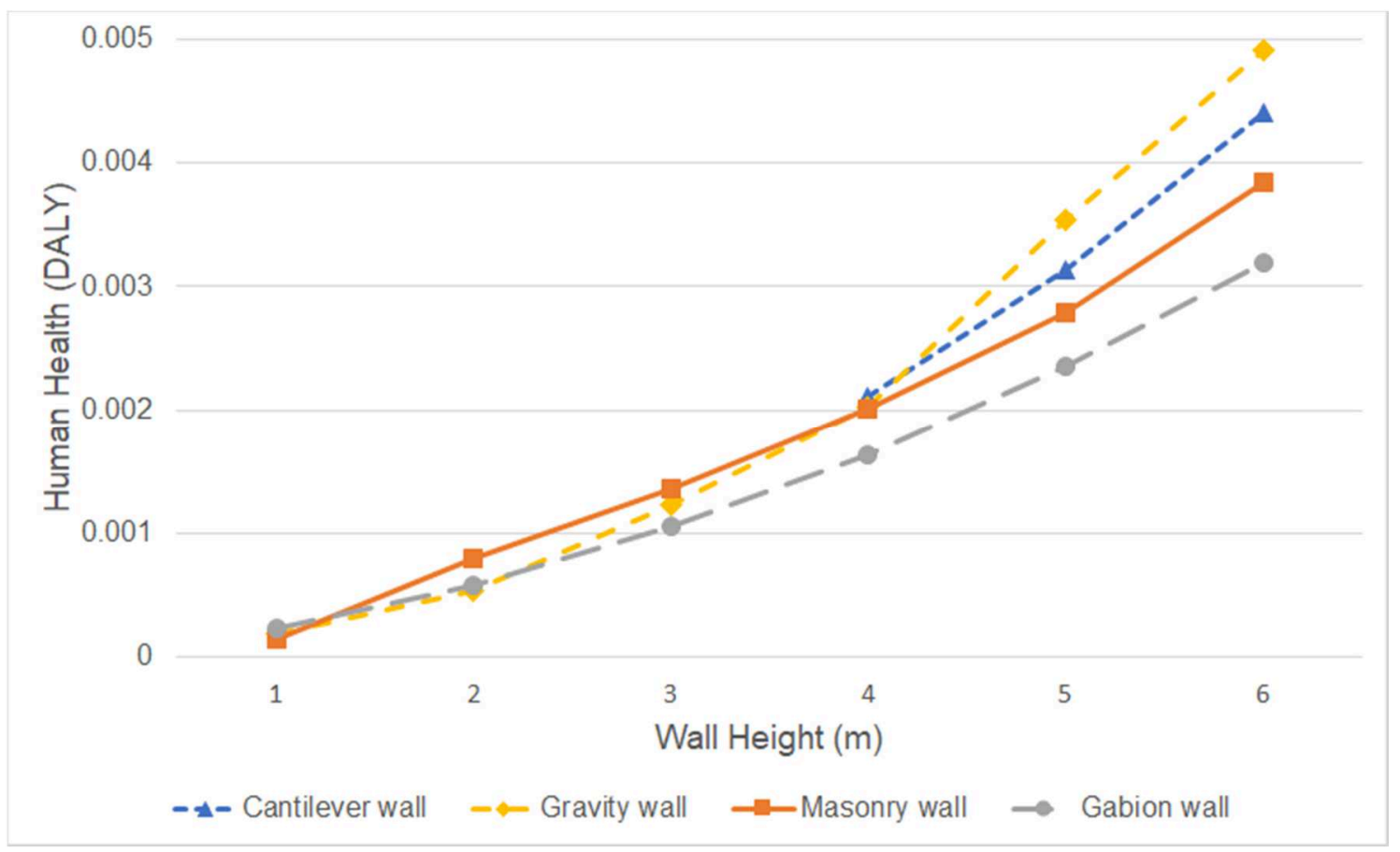

Fig. 8. Development of the human health endpoint impact with regard to wall height 


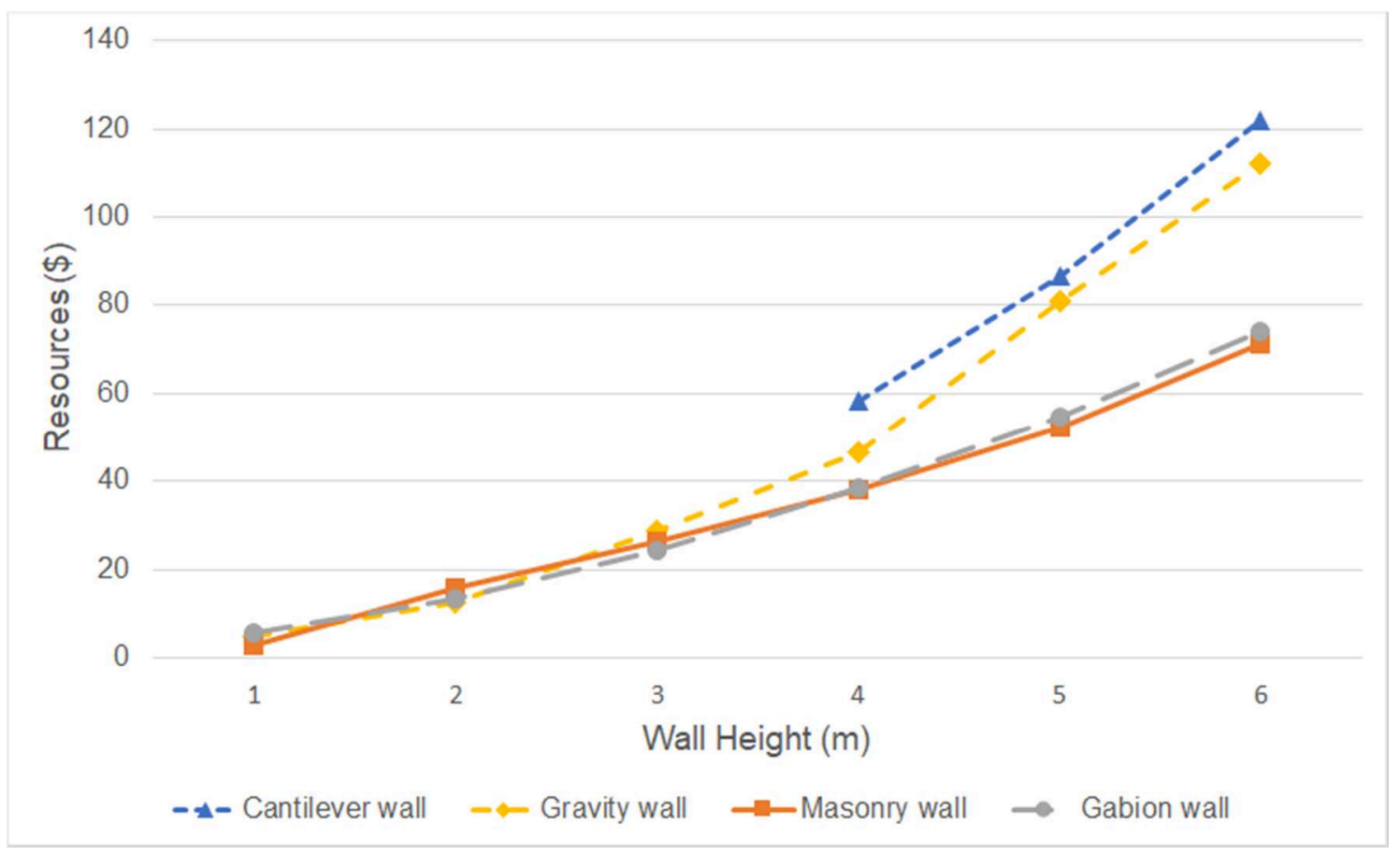

Fig. 9. Development of the resources endpoint impact with regard to wall height

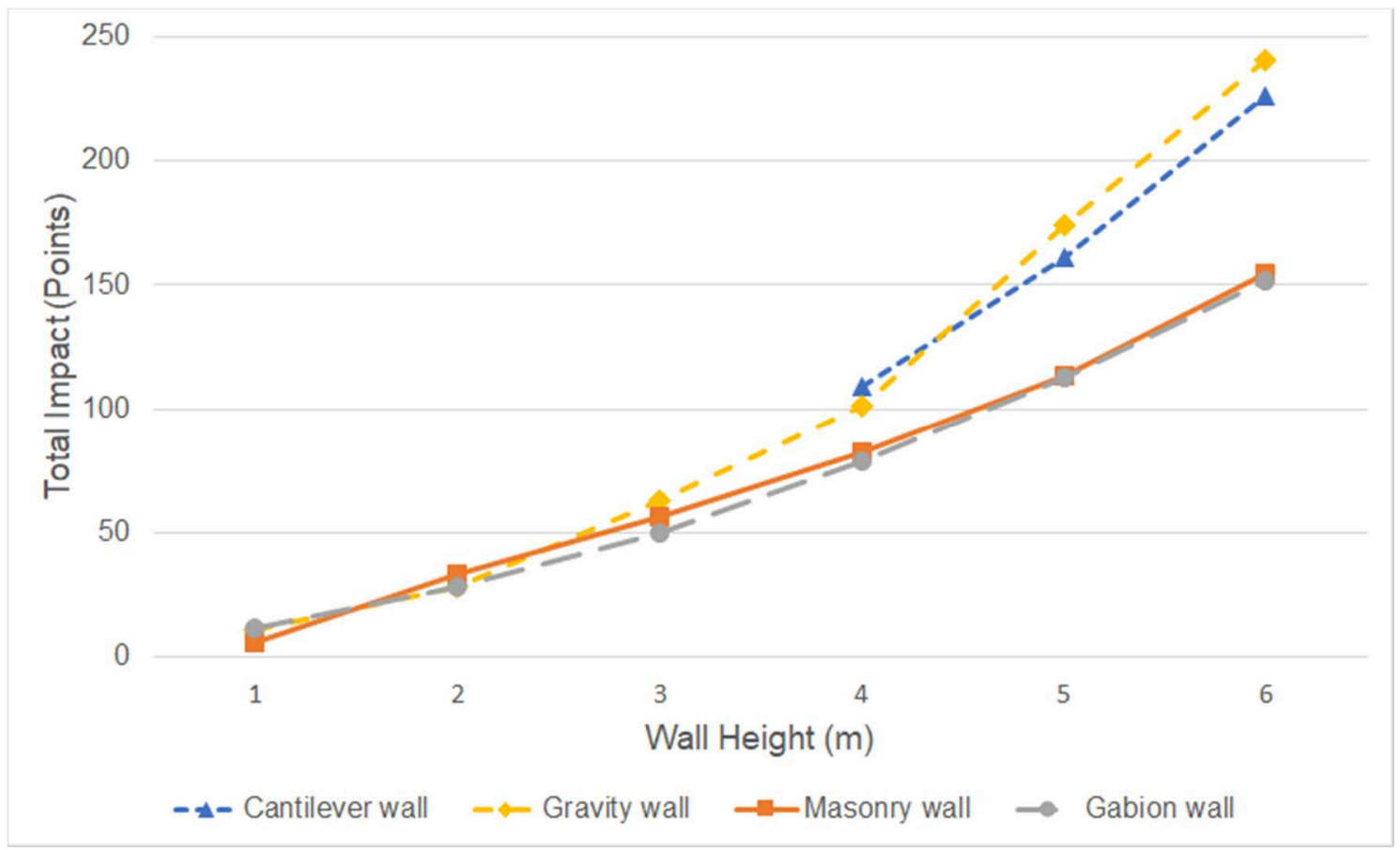

Fig. 10. Development of the normalized global impact with regard to wall height 


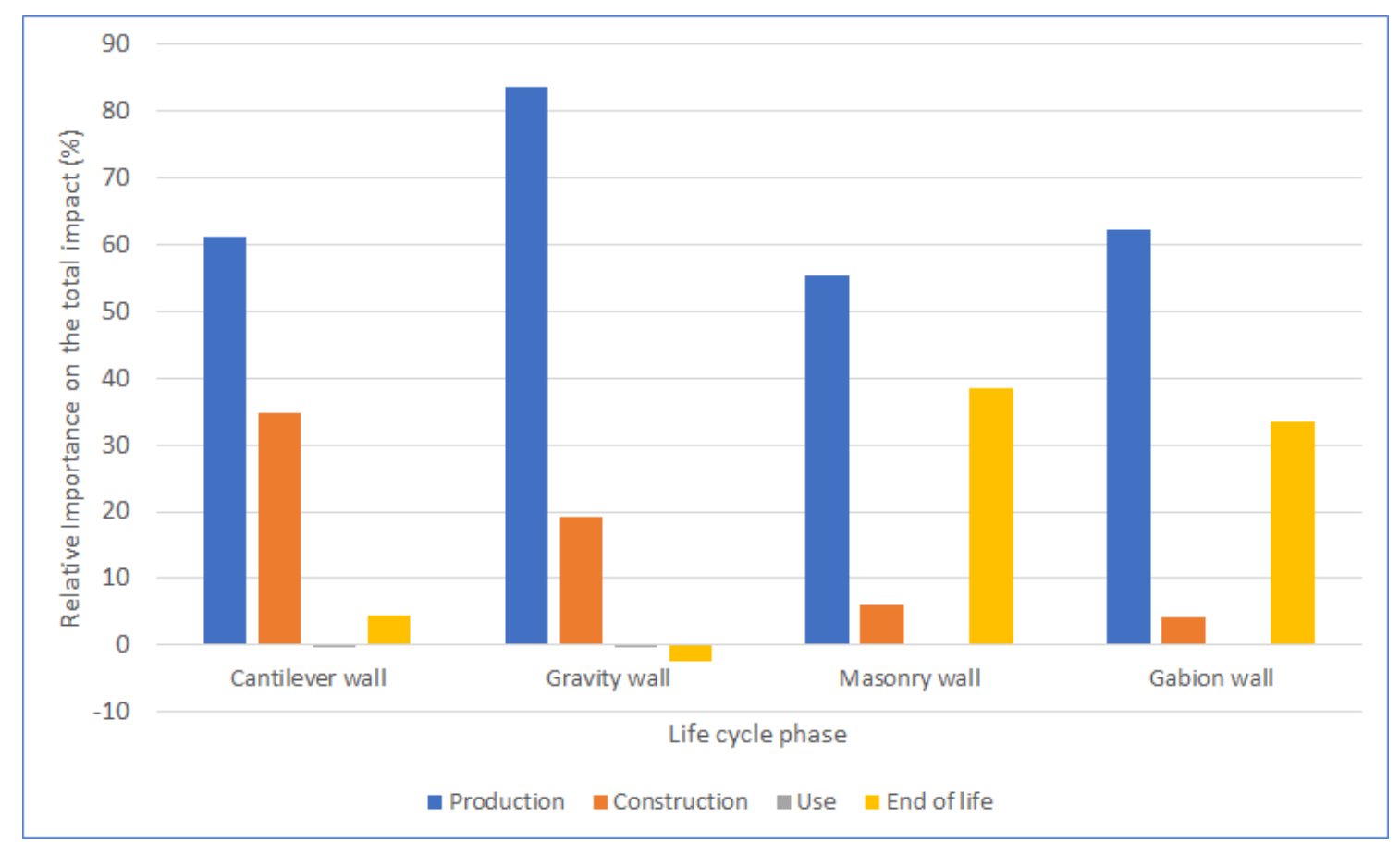

Fig. 11. Relative importance on the total impact for $4 \mathrm{~m}$ high walls 
Table 1. Amount of materials per linear meter of wall

\begin{tabular}{ccccccc}
\hline Cantilever wall height $(\mathrm{m})$ & 1 & 2 & 3 & 4 & 5 & 6 \\
\hline$V_{\text {concrete }}\left(\mathrm{m}^{3}\right)$ & & & & 1.74 & 2.88 & 4.42 \\
$m_{\text {steel }}(\mathrm{kg})$ & & & & 100.1 & 164.7 & 249.7 \\
$A_{\text {formwork }}\left(\mathrm{m}^{2}\right)$ & & & & 8 & 10 & 12 \\
$V_{\text {excavation }}\left(\mathrm{m}^{3}\right)$ & & & & 0.76 & 1.21 & 1.87 \\
$V_{\text {backfill }}\left(\mathrm{m}^{3}\right)$ & & & & 18.28 & 24.35 & 30.9 \\
\hline Gravity wall height $(\mathrm{m})$ & 1 & 2 & 3 & 4 & 5 & 6 \\
\hline$V_{\text {concrete }}\left(\mathrm{m}^{3}\right)$ & 0.35 & 1.1 & 2.85 & 4.8 & 8.75 & 12.3 \\
$A_{\text {formwork }}\left(\mathrm{m}^{2}\right)$ & 2.41 & 4.83 & 7.24 & 9.66 & 12.07 & 14.49 \\
$V_{\text {excavation }}\left(\mathrm{m}^{3}\right)$ & 0.23 & 0.46 & 0.69 & 0.92 & 1.15 & 1.38 \\
$V_{\text {backfill }}\left(\mathrm{m}^{3}\right)$ & 0.5 & 2 & 4.5 & 8 & 12.5 & 18 \\
\hline Masonry wall height $(\mathrm{m})$ & 1 & 2 & 3 & 4 & 5 & 6 \\
\hline$V_{\text {stone }}\left(\mathrm{m}^{3}\right)$ & 0.57 & 2.42 & 4.69 & 7.04 & 10.03 & 14.09 \\
$V_{\text {sand }}\left(\mathrm{m}^{3}\right)$ & 0.16 & 0.77 & 1.35 & 2.12 & 3.05 & 4.15 \\
$m_{\text {cement }}(\mathrm{kg})$ & 32 & 163 & 286 & 449 & 644 & 918 \\
$V_{\text {water }}(\mathrm{l})$ & 30 & 147 & 258 & 409 & 589 & 801 \\
\hline Gabion wall height $(\mathrm{m})$ & 1 & 2 & 3 & 4 & 5 & 6 \\
\hline$V_{\text {stone }}\left(\mathrm{m}^{3}\right)$ & 1 & 2.5 & 4.5 & 7 & 10 & 13.5 \\
$m_{\text {steel }}(\mathrm{kg})$ & 13 & 31 & 55 & 86 & 122 & 164 \\
$V_{\text {backfill }}\left(\mathrm{m}^{3}\right)$ & 0.5 & 2 & 4.5 & 8 & 12.5 & 18
\end{tabular}


Table 2. Impacts caused by $4 \mathrm{~m}$ high walls. Mean value and coefficient of variation (cv)

\begin{tabular}{|c|c|c|c|c|c|c|c|c|c|}
\hline \multirow[t]{2}{*}{ Acronym } & \multirow[t]{2}{*}{ Unit } & \multicolumn{2}{|c|}{ Cantilever wall } & \multicolumn{2}{|c|}{ Gravity wall } & \multicolumn{2}{|c|}{ Masonry wall } & \multicolumn{2}{|c|}{ Gabion wall } \\
\hline & & mean & cv (\%) & mean & cv (\%) & mean & cv (\%) & mean & cv (\%) \\
\hline ALO & $\mathrm{m}^{2 *} \mathrm{a}$ & 206.02 & 19.62 & 235.21 & 21.72 & 13.37 & 9.12 & 36.57 & 5.64 \\
\hline GWP & $\mathrm{kg} \mathrm{CO}_{2} \mathrm{eq}$ & 907.43 & 17.61 & 1025.58 & 29.47 & 915.08 & 2.63 & 629.23 & 5.19 \\
\hline FD & $\mathrm{kg}$ oil eq & 266.97 & 11.29 & 273.24 & 8.99 & 201.14 & 4.27 & 198.37 & 5.80 \\
\hline FEPT & kg 1,4-DB eq & 11.18 & 10.23 & 6.11 & 16.30 & 3.47 & 3.48 & 3.88 & 4.54 \\
\hline FEP & $\mathrm{kg} P$ eq & 0.26 & 11.43 & 0.21 & 19.25 & 0.10 & 2.24 & 0.11 & 4.11 \\
\hline HTP & kg 1,4-DB eq & 432.69 & 9.45 & 258.75 & 17.21 & 124.92 & 4.71 & 128.76 & 6.31 \\
\hline IRP & $\mathrm{kg}$ U235 eq & 145.73 & 11.03 & 100.56 & 10.22 & 74.93 & 4.17 & 59.64 & 4.72 \\
\hline MEPT & kg 1,4-DB eq & 11.19 & 9.93 & 6.18 & 15.96 & 3.51 & 4.48 & 3.99 & 5.63 \\
\hline MEP & $\mathrm{kg} \mathrm{N} \mathrm{eq}$ & 0.23 & 12.73 & 0.21 & 12.29 & 0.18 & 3.81 & 0.19 & 4.94 \\
\hline MD & $\mathrm{kg} \mathrm{Fe}$ eq & 221.47 & 7.72 & 49.78 & 11.38 & 25.34 & 2.09 & 80.09 & 4.02 \\
\hline NLT & $\mathrm{m}^{2}$ & -0.92 & 28.32 & -0.43 & 28.23 & -0.74 & 27.01 & -1.00 & 26.23 \\
\hline ODP & kg CFC-11 eq & $1.27 \mathrm{E}-04$ & 11.97 & $1.20 \mathrm{E}-04$ & 5.84 & $9.71 \mathrm{E}-05$ & 4.64 & $9.54 \mathrm{E}-05$ & 6.19 \\
\hline PMFP & kg PM10 eq & 2.40 & 11.55 & 2.08 & 12.70 & 2.50 & 2.55 & 2.62 & 3.39 \\
\hline POFP & kg NMVOC & 5.41 & 11.88 & 4.85 & 10.25 & 4.62 & 4.17 & 4.59 & 5.61 \\
\hline TAP & $\mathrm{kg} \mathrm{SO}_{2}$ eq & 4.35 & 12.67 & 4.23 & 12.56 & 3.42 & 3.64 & 3.45 & 4.86 \\
\hline TETP & kg 1,4-DB eq & 0.14 & 16.94 & 0.11 & 10.76 & 0.05 & 17.70 & 0.34 & 5.75 \\
\hline ULO & $m^{2 *} a$ & 54.23 & 15.58 & 30.91 & 7.63 & 19.76 & 12.80 & 29.54 & 11.26 \\
\hline WD & $\mathrm{m}^{3}$ & 3835.75 & 20.63 & 2473.66 & 16.23 & 1485.90 & 4.37 & 1947.02 & 3.71 \\
\hline
\end{tabular}


Table 3. Main element contributors for every midpoint impact

\begin{tabular}{ccccccccc}
\hline Acronym & \multicolumn{2}{c}{ Cantilever wall } & \multicolumn{2}{c}{ Gravity wall } & \multicolumn{2}{c}{ Masonry wall } & \multicolumn{2}{c}{ Gabion wall } \\
\hline & Name & $(\%)$ & Name & $(\%)$ & Name & $(\%)$ & Name & $(\%)$ \\
\cline { 2 - 8 } ALO & Formwork & $82.9-78.3$ & Formwork & $96.7-83.9$ & Landfill & $49.7-44.0$ & Steel wire & $70.9-66.1$ \\
GWP & Concrete & $43.1-53.1$ & Concrete & $83.0-114.3$ & Cement & $23.7-38.7$ & Demolition & $31.4-31.3$ \\
FD & Construction & $34.3-27.7$ & Concrete & $35.8-53.2$ & Demolition & $43.6-47.9$ & Demolition & $34.7-34.2$ \\
FEPT & Rebar & $52.9-58.9$ & Concrete & $59.6-72.8$ & Cement & $30.2-34.2$ & Steel wire & $61.8-57.6$ \\
FEP & Rebar & $46.4-51.2$ & Concrete & $68.1-81.3$ & Cement & $45.3-48.8$ & Steel wire & $71.2-67.5$ \\
HTP & Rebar & $53.7-59.2$ & Concrete & $62.0-75.4$ & Cement & $30.2-33.5$ & Steel wire & $51.3-47.0$ \\
IRP & Gravel & $53.2-47.1$ & Concrete & $41.8-53.7$ & Cement & $39.6-45.1$ & Gravel & $23.4-32.8$ \\
MEPT & Rebar & $52.3-58.3$ & Concrete & $58.8-71.6$ & Cement & $28.4-31.9$ & Steel wire & $57.2-52.9$ \\
MEP & Construction & $32.0-26.5$ & Concrete & $46.8-62.1$ & Demolition & $25.6-26.2$ & Stone & $22.4-21.7$ \\
MD & Rebar & $71.3-77.1$ & Concrete & $45.9-56.6$ & Demolition & $37.2-41.3$ & Steel wire & $74.5-71.3$ \\
NLT & Landfill & $(-) 180-187$ & Landfill & $(-) 286-333$ & Landfill & $(-) 113-119$ & Landfill & $(-) 127-125$ \\
ODP & Construction & $41.3-34.7$ & Concrete & $28.3-43.8$ & Demolition & $44.8-51.5$ & Demolition & $38.2-37.2$ \\
PMFP & Rebar & $21.5-26.1$ & Concrete & $47.2-63.4$ & Stone & $48.9-46.7$ & Stone & $43.0-42.2$ \\
POFP & Concrete & $19.1-22.0$ & Concrete & $41.2-56.2$ & Demolition & $28.2-29.4$ & Stone & $21.7-20.8$ \\
TAP & Concrete & $20.8-26.3$ & Concrete & $47.0-63.0$ & Demolition & $27.5-23.4$ & Steel wire & $23.4-21.3$ \\
TETP & Rebar & $22.0-27.0$ & Concrete & $36.3-50.3$ & EoL transport & $34.4-35.8$ & Steel wire & $81.7-79.1$ \\
ULO & Landfill & $36.1-34.3$ & Concrete & $30.1-44.7$ & Landfill & $58.9-58.1$ & Landfill & $48.6-48.1$ \\
WD & Gravel & $51.7-43.1$ & Concrete & $63.4-70.3$ & Cement & $62.0-63.9$ & Steel wire & $69.7-62.1$ \\
\hline
\end{tabular}

